\title{
Os Manuscritos de 1844 de Karl Marx e a retomada da economia política no pensamento pós-hegeliano
}

\author{
Douglas Rafael Dias Martins ${ }^{1}$
}

\section{Resumo:}

O presente artigo visa à análise e caracterização das rupturas e continuidades presentes nos manuscritos produzidos em Paris por Karl Marx no ano de 1844 a partir das relações com a economia política, com o pensamento póshegeliano e Hegel. Nesse sentido, os cadernos intitulados Manuscritos econômico-filosóficos foram produzidos a partir das preocupações filosóficas da tradição dos novos hegelianos que se formou após a morte de Hegel - e se estendeu até meados da metade do século XIX -, e ocupam uma posição privilegiada no desenvolvimento do pensamento de Marx pois permitem apreender o movimento dos diálogos e práticas que o autor estabelecia. Ainda, ao retomar os estudos da economia política junto a uma interpretação da dialética hegeliana, Marx realiza um movimento de, ao mesmo tempo, aproximar-se e afastar-se de Hegel, bem como aproximar-se e afastar-se dos jovens hegelianos. A partir de uma análise crítica e da reconstituição do cenário de produção dos manuscritos, buscamos deixar apontada a importância da reaproximação crítica da economia política com a dialética hegeliana para a importância do destaque e prevalência do pensamento de Marx em meio a estes pós-hegelianos.

Palavras-chave: Karl Marx; economia política; pós-hegelianos; dialética

\section{Karl Marx's 1844 Manuscripts and the return of the political economy in post-Hegelian thought}

\section{Abstract:}

This article aims to analyze and characterize the ruptures and continuities present in the manuscripts produced in Paris by Karl Marx in the year 1844 from the relations with political economy, with post-Hegelian and Hegel thought. In this sense, the notebooks entitled Economic-philosophical manuscripts were produced from the philosophical concerns of the tradition of new Hegelians that was formed after Hegel's death - and extended until the middle of the 19th century -, and occupy a privileged position in the development of Marx's thought because they allow to apprehend the

${ }^{1}$ Mestrando do Programa de Pós-Graduação em Filosofia da Universidade Estadual Paulista (Unesp).E-mail: douglas__martins@hotmail.com. 
movement of dialogues and practices that the author established. Still, after he resumes the studies of political economy with an interpretation of the Hegelian dialectic, Marx makes a movement, at the same time, to approach and distance himself from Hegel, as well as to approach and distance himself from the young Hegelians. Based on a critical analysis and the reconstitution of the manuscript production scenario, we seek to point out the importance of the critical rapprochement between political economy and Hegelian dialectic for the importance of the prominence and prevalence of Marx's thought among these post-Hegelians.

Keywords: Karl Marx; political economy; post-Hegelians; dialectic.

\section{Introdução}

Buscaremos analisar a evolução do pensamento de Karl Marx a partir das rupturas e continuidades que este sofreu e promoveu a partir das relações e debates com os intelectuais alemães pós-hegelianos, os socialistas franceses, a economia política e o próprio Hegel. Para tanto, consideramos que alguns textos ganham evidência por sua posição histórica, política e epistemológica privilegiada, de modo que os intitulados Manuscritos econômico-filosóficos é um conjunto desses escritos e apresenta os primeiros traços que prepararão a ruptura dialética de Marx com os pós-hegelianos dos anos seguintes. Também buscaremos apontar, além da importância para o pensamento de Karl Marx, os manuscritos produzidos no ano de 1844 em Paris como uma tentativa - não levada à cabo por não terem sido publicados - de retomada e consolidação da economia política junto ao pensamento pós-hegeliano (que havia sido esquecida pelos herdeiros diretos, os chamados velhos hegelianos) antes da dissolução de seu domínio intelectual na Alemanha na metade do século XIX.

Nesses marcos, destaca-se que a virada dos anos de 1843 e 1844 em Karl Marx deve ser analisada com cuidado. Após a metade do ano de 1843 o jovem passa por mudanças bastante amplas: desde o casamento com a noiva Jenny, a fundação de uma revista - os Anais Franco-Alemães [Deutsch-französische Jarhbücher] -, até a mudança com a família para Paris e os primeiros contatos com organizações proletárias. Nesse período, ao todo, surgem pelo menos seis escritos $^{2}$ do autor, ao passo que nem todos foram publicados e acabaram servindo como material de estudos e pesquisa. $\mathrm{O}$ cuidado, então, se deve à caracterização dos distintos momentos da vida e do pensamento de Marx, de

${ }^{2}$ São eles: Crítica da filosofia do direito de Hegel; Sobre A questão judaica; Crítica da filosofia do direito de Hegel - Introdução; os Manuscritos econômico-filosóficos de 1844; Glosas críticas marginais ao artigo "O rei da Prússia e a reforma social". De um prussiano; e por fim, A sagrada família. 
modo que, ainda que a produção desses escritos se deu em um período bastante curto, também serviu para que ele percorresse um longo caminho filosófico e político. Assim, entre junho de 1843 e novembro de 1844, as concepções e posicionamentos do autor mudam e se aprofundam, principalmente, na direção do comunismo e dos estudos sociais.

Ainda nas primeiras décadas do século XIX a Alemanha era uma região atrasada do ponto de vista socioeconômico, guardando muitos resquícios da produção social fundamentada em guildas e no trabalho artesanal, assim como nas relações de servidão. Da mesma maneira, ainda não havia se constituído como nação, mantendo-se como uma série de pequenos reinos que se relacionavam e uniam através de interesses em comum com outros reinos maiores, que por sua vez, visavam a satisfazer principalmente as classes da nobreza, do clero e dos proprietários fundiários. Apesar desse atraso socioeconômico, que contrastava com seu desenvolvimento filosóficocientífico, algumas grandes cidades alemãs já continham elementos razoavelmente avançados, como grandes manufaturas e fábricas isoladas, de modo que o processo de proletarização dos servos, artesãos e camponeses (principalmente) havia apenas começado. Contudo, ainda que esses elementos servissem para iniciar a introdução da consciência proletária nas massas trabalhadoras e nos intelectuais da Alemanha, as condições sociais conservadoras ainda não permitiam que estes grupos estivessem na vanguarda de suas áreas de atuação política. Assim, a recém-nascida e ainda pouco numerosa classe trabalhadora alemã, bem como os pensadores e intelectuais que refletiam sobre as condições das camadas populares, não foram capazes de produzir mudanças radicais nas relações econômicas e políticas daquela região na virada e nas primeiras décadas do século XIX.

Assim, os intelectuais pós-hegelianos de maneira geral buscaram refletir por uma via filosófica sobre as condições da cultura alemã, mas, especialmente seus herdeiros diretos - os chamados velhos hegelianos - não deram a mesma atenção que o próprio Hegel dedicara ao tema da economia política em seu tempo3. Será, no entanto, pelas mãos e atuação dos jovens hegelianos que o tema da economia política será gradualmente retomado como uma questão de interesse do pensamento hegeliano - ainda que se ressalte a existência de uma anotação do "velho" Gans4 sobre o tema. Somente a partir da década de 1840 que algumas questões da economia política passarão a

${ }_{3}^{3}$ Como esclarece Norbert Waszek, em O estatuto da economia política na filosofia prática de Hegel.

4 Waszek aponta que na segunda edição da Filosofia do direito publicada em 1833, Eduard Gans, discípulo direto de Hegel, "velho hegeliano" e professor de Marx, escreveu: "Neste livro, nada que poderia se reportar ao estado é, portanto, deixado de lado. As questões políticas são tratadas de modo detalhado e, mesmo a ciência da economia política encontrou o lugar e o tratamento que lhe convém, na sociedade civil." (WASZEK, 2011, p. 56) 
exercer alguma influência sobre os intelectuais neo-hegelianos como por exemplo Moses Hess, Friedrich Engels e Karl Marx. Partindo da compreensão de que a economia política começava a ser consolidada no pensamento filosófico alemão a partir da introdução tardia das relações de produção capitalistas, e considerando que o próprio Hegel havia se detido mais do que seus herdeiros para o mesmo tema, buscaremos ter como objeto e fio condutor a compreensão do pensamento de Marx a partir das aproximações e distanciamentos com Hegel, os pós-hegelianos, os socialistas "utópicos" e os economistas políticos no referido texto.

\section{Sobre os cadernos de estudos e os Manuscritos de Paris}

Os manuscritos escritos em Paris por Karl Marx foram publicados, parcialmente, em 1927, e apenas cinco anos depois foram publicados integralmente sob o título de Manuscritos econômico-filosóficos. A descoberta dos cadernos que serviram de estudos e os manuscritos que Marx escreveu5, com a pretensão de publicar, foram extremamente importantes não somente do ponto de vista do fornecimento de novos materiais para a compreensão da evolução do pensamento marxiano, como também aconteceu em um período chave do desenvolvimento da história do proletariado e das lutas de classes no século XX. O ano de $1927^{6}$, inclusive, com a publicação desses primeiros fragmentos dos manuscritos, influenciou, junto às obras de Karl Korsch, György Lukács, Isaak Ilitch Rubin e Evgeni Pachukanis7, a ascensão de outras tendências filosóficas no interior do pensamento marxista e que terão em comum a busca por revalorizar as relações do pensamento tardio de Marx e Engels com as novas descobertas de obras de juventude não publicadas assim como suas ligações com os jovens hegelianos, Ludwig Feuerbach e o

5 Cabe fazer uma pequena distinção: os cadernos de anotações, publicados no Brasil como Cadernos de Paris (MARX, 2015, pp. 179-233), se tratam das notas de estudos que visavam fundamentar os manuscritos que seriam publicados, e não o foram, mas que seriam encontrados e publicados no século XX como Manuscritos econômico-filosóficos (MARX, 2010a).

6 A partir de 1924 marcaria, ainda, um giro fundamental nas políticas programáticas da Internacional Comunista - que já tinha força de direção significativa sobre as massas de trabalhadores de diversos países do mundo -, culminando nas décadas seguintes, em última instância, com a identificação das interpretações teóricas com a concepção do "terceiro período" e do "socialismo em um só país". Assim, principalmente após a supressão dos conselhos de trabalhadores, a perseguição e morte de uma série de dirigentes, militantes e intelectuais revolucionários bolcheviques (ou que aderiram ao processo revolucionário), surge a noção de um "marxismo ocidental" - que não possui uma unidade teórica ou prática, mas que foi usada inicialmente por Korsch e posteriormente reproduzida por Merleau-Ponty como oposição a um "marxismo vulgar" defendido como "doutrina oficial" no interior da Internacional Comunista.

7 Respectivamente Marxismo e filosofia, História e consciência de classe, A teoria marxista do valor e Teoria geral do direito e marxismo. 
pensamento de G. W. F. Hegel - e as questões colocadas por aquele período histórico.

Nos Manuscritos econômico-filosóficos, o grau de importância da retomada do tema e das questões da economia política ${ }^{8}$, para além do que foi brevemente dito, também vão marcar - segundo Mandel - o início da evolução de um "comunismo filosófico" para um "comunismo sociológico, isto é, fundado na análise da evolução das sociedades e de sua lógica” (MANDEL, 1968, p. 32). Um dos pontos principais dessa influência, sem dúvida, foram as experiências que o próprio Marx reivindicou para seus estudos como "resultados (...) de uma análise inteiramente empírica, baseada em cuidadoso estudo crítico da economia política”, que embora muito menos profundas e críticas do que o jovem autor gostaria, já eram bastante importantes do ponto de vista da constatação do nível de organização política que o proletariado francês e imigrante estava adquirindo. Nos Manuscritos, vemos o jovem autor se fundamentar, do ponto de vista da economia política, principalmente em Adam Smith, mas também em fragmentos e questões pontuais de David Ricardo, Jean-Baptiste Say, James Mill, Thomas Malthus, Sismonde de Sismondi, Pierre-Joseph Proudhon, entre outros (MARX, 2010a, p. 20).

Serão baseados ainda nesses manuscritos, como nos informa Jones na biografia do autor, que nos últimos meses de 1844 Marx teve um papel ativo na revista Vorwärts! - experiência esta que o permitiu conhecer e se aproximar da Liga dos Justos (o germe da futura Liga dos Comunistas) -, e chegou inclusive a ministrar palestras sobre economia política para os trabalhadores 9 . Este fato possui importância pois ajuda a esclarecer e refletir sobre a importância que o jovem autor já considerava na exposição e apreensão

\footnotetext{
8 Em que Marx anuncia conscientemente sua intenção de aproximar a questão da dialética com uma noção crítica da economia política: "Farei, por conseguinte e sucessivamente, em diversas brochuras independentes, a crítica do direito, da moral, da política etc., e por último, num trabalho específico, a conexão do todo, a relação entre as distintas partes, demarcando a crítica da elaboração especulativa deste mesmo material. Assim, será encontrado o fundamento, no presente escrito, da conexão entre a economia nacional e o estado, o direito, a moral, a vida civil etc., na medida em que a economia nacional mesma, ex professo, trata destes objetos. (...) Considerei o capítulo final do presente texto, a exposição da dialética e da filosofia hegelianas em geral, extremamente necessário, posto que semelhante trabalho jamais foi realizado, e nem sequer chegou a ter sua necessidade reconhecida pelos teólogos críticos do nosso tempo." (MARX, 2010a, pp. 19-20)

9 Onde é interessante notar que, como ainda apresentaremos, essas palestras sobre economia política promovidas para os trabalhadores representam bem as influências filosóficas e políticas das posições de Marx nesse momento de 1844: "De agosto até o final de 1844, Karl teve papel ativo na Vorwärts!, fazendo palestras para artesãos e definindo a linha editorial da Liga. Ele escreveu para Feuerbach dizendo que 'os artesãos alemães em Paris, isto é, aqueles que são comunistas, algumas centenas', têm assistido a palestras, duas vezes por semana, sobre A essência do cristianismo, 'durante todo este verão'. Karl e outros do periódico, especialmente Georg Weber, davam palestras sobre economia política, tendo como base o ensaio crítico de Engels sobre o assunto, o texto de Hess sobre dinheiro e os manuscritos do próprio Karl." (JONES, 2017, p. 187)
} 
de sua filosofia e análises políticas e socioeconômicas para os indivíduos que consideravam essenciais na constituição como sujeito ou classe social, bem como a importância que seu pensamento posterior irá adquirir para compreender a totalidade da sociedade capitalista. Essa consideração, inclusive, é de grande importância para o próprio Karl, que como analisaremos, busca partir dos elementos mais sensíveis e imediatos aos trabalhadores em suas análises e críticas da economia política - perceptível não apenas nos Manuscritos econômico-filosóficos como também em sua obra de maior fôlego e maturidade, O capital (JONES, 2017, p. 187).

Para além do Prefácio dos Manuscritos parisienses situado no terceiro caderno, Marx reforça sua influência filosófica junto às críticas neo-hegelianas de Feuerbach e sua posição "humanista e naturalista" (MARX, 2010a, p. 20), que parte da sensibilidade como início do processo de apreensão racional da realidade e dá um novo sentido para o conceito de alienação: Hegel, segundo a crítica feuerbachiana, teria cometido um erro ao iniciar sua lógica com o ser e o nada, bem como, teria considerado o processo de exteriorização da essência do ser, a alienação e o mundo natural e sensível, como mero momento de mediação da reconciliação com o espírito absoluto. Mergulhado na crítica de Feuerbach, Marx, então, repreende Hegel por seu aspecto "místico" que, segundo ele, não teria dado suficiente atenção para o caráter negativo da vida sensível como finito, alertando para a possibilidade de a filosofia especulativa hegeliana ser apropriada como o último refúgio das ideias conservadoras daquele tempo.

Refletindo sobre a questão dos salários, Marx avança em seus escritos, em relação à literatura anterior, ao concebê-los a partir de um processo de disputa, um "confronto hostil entre capitalista e trabalhador" (MARX, 2010a, p. 23). Apesar de seus equívocos - que serão tratados logo à frente -, trata-se de um passo importante a noção mais geral de que os salários não representam o produto justo da atividade de trabalho do indivíduo trabalhador, mas sim que eles pressupõem relações de produção entre indivíduos e grupos sociais com interesses opostos e contraditórios. O salário, assim, passará a caracterizar a manifestação, a mediação universal, da essência alienada da atividade de trabalho na sociedade moderna. Contudo, como se nota através das notas de leitura que foram produzidas para a elaboração dos Manuscritos econômicos e filosóficos, e partindo de Adam Smith, a "taxa natural do salário" para Marx - assim como a renda e o lucro -, será determinada de um modo bastante eclético, através "do costume e do monopólio e, em última instância, da concorrência; não derivam da natureza da terra, do capital e do trabalho" Por fim, ainda reafirma: "Os custos de produção são eles mesmos determinados pela concorrência e não pela produção.” (MARX, 2015, p. 191)

Essa concepção equivocada de Marx, que levava em consideração principalmente as noções ainda rudimentares sobre Ricardo e Malthus e três 
momentos do desenvolvimento do ciclo econômico, somente mudaria cerca de 10 anos depois segundo Mandel. Apesar de nunca ter aderido explícita e completamente às mesmas, a teoria ricardiana e malthusiana dos salários ajudou Marx - e Engels - a formular sua própria noção, que nos escritos marxianos já tem suas primeiras evidências nos Manuscritos econômicofilosóficos - através da concepção de que existia uma "tendência dos salários de cair para um mínimo vital fisiológico e aí se manter” (MANDEL, 1968, p. 145). Para o jovem Marx, ainda, uma vez constatado esse fenômeno, que era inclusive defendido pelos teóricos da economia política, se tornava explícito que os trabalhadores eram tomados apenas como simples fatores de produção, ou melhor, seres brutalizados e portadores apenas de carências fisiológicas voltadas para a mera existência e reprodução biofísicas.

Nesses marcos, e com todos seus limites, essa primeira teoria dos salários do jovem Marx compreenderá que os "aumentos de salários não podem intervir senão provisoriamente e estão condenados a ser impiedosamente apagados pela lógica do sistema” (MANDEL, 1968, p. 34). Sua teoria, então, se caracterizará pela "pauperização relativa” dos salários, em que o aumento da produtividade frente a qualquer situação de rápida baixa de valor de uma mercadoria, será compensada em uma fração cada vez menor da jornada de trabalho - o colocando em uma posição oposta à de Smith, que por sua vez defende que a classe trabalhadora deterá uma massa cada vez maior da riqueza social. É aqui que, para o autor, a economia política reforçava seu caráter de uma ciência positiva, já que se assumindo como "ciência da riqueza" omitia que somente a produzia baseada na concentração da mesma e, por isso, em uma distribuição da pobreza. Desse modo, a massa de trabalhadores que participava diretamente da produção dessa riqueza, na visão de Marx, não estava apenas alheia e marginalizada dos produtos e excedentes dessa mesma riqueza social, como também a objetivação de sua atividade genérica se torna um meio apenas para garantir sua sobrevivência individual. Ainda irá escrever nos seus cadernos de estudos que se a produção de riqueza "é o objetivo da vida, a economia política atende-o muito mal, porque, para ela, consumir e produzir não são o destino do operário" (MARX, 2015, p. 196).

Notamos aqui que, diferentemente de Hegel que via na possibilidade de recuperação de um certo caráter formador do trabalho, o período histórico e os primeiros estudos da economia política já permitiram que Marx percebesse as condições brutalizadas que os trabalhadores modernos eram constituídos. Assim, o jovem já denunciava os teóricos da economia política, para quem os indivíduos que deveriam ser considerados e tomados como efetivos eram os sujeitos econômicos racionais - o bourgeois e não o citoyen, como escreveu em Sobre a questãojudaica (MARX, 2010b, p. 41). Apesar dessa compreensão, a crítica marxiana não tinha as questões econômicas hegelianas como alvo, mas sim a defesa do sistema de crédito levado à cabo pelos socialistas 
utópicos ${ }^{10}$ e, em especial, Proudhon: desde esse período Marx já era capaz de perceber que as contradições da economia política pressupunham a base e o desenvolvimento do sistema bancário como um de seus meios de reprodução, e por isso, o próprio sistema de créditos e a generalização do dinheiro se manifestavam como soluções aparentes e ilusórias (MARX, 2015, p. 205).

Também será através da questão dos salários que se conectará outro tema em um dos últimos capítulos do terceiro manuscrito: a questão do dinheiro. Em relação a este, em seus cadernos de leitura de 1844 Marx faz alguns comentários sobre James Mill e concorda com um aspecto da concepção do mesmo: o que caracteriza o dinheiro não é sua alienação da propriedade, mas sim da atividade humana - do trabalho -, ou seja, uma vez que a riqueza é produzida a partir do trabalho social ela necessita de uma forma específica de representação da mesma e que seja externa ao mesmo trabalho. O dinheiro, então, originalmente, seria uma exteriorização da atividade de trabalho que mediava a quantidade de riqueza contida em cada produto da mesma; contudo, com a alienação do trabalho, essa determinação se inverte, e é a quantidade de trabalho que passa a mediar a exteriorização do dinheiro no processo de produção de riqueza. Escreverá em seus cadernos preparatórios:

Não é o dinheiro que se suprime no homem no interior do sistema creditício; é o próprio homem que se converte em dinheiro ou, noutra expressão, é o dinheiro que se encarna no homem. A individualidade humana, a moral humana, transformam-se, simultaneamente, em artigo de comércio e na existência material do dinheiro. Em lugar do dinheiro, do papel, é a minha existência pessoal, a minha carne e o meu sangue, a minha virtude social e a minha reputação social que se tornam a matéria e o corpo do espírito do dinheiro. $\mathrm{O}$ crédito calcula o valor monetário não em dinheiro, mas em carne e coração humanos. (MARX, 2015, p. 206)

Segundo o jovem nos Manuscritos econômico-filosóficos, todavia, as relações dos indivíduos com o dinheiro não se manifestavam como um fenômeno de alienação como os demais - como o da religião retratado por Feuerbach, por exemplo. Agora, como dirá Bensaïd, o dinheiro aparecerá "principalmente como um culto arcaico", como "fetichismo", em que este "mexe as cordas do mundo", assim como “domina e tiraniza a humanidade (...)

10 Marx dá de exemplo em seus cadernos de estudos os herdeiros de Saint-Simon, que consideravam o desenvolvimento do dinheiro, das letras de câmbio, a substituição do dinheiro por papeis, o sistema de crédito e bancário, como o início da abolição da separação entre sujeito e objeto, capital e trabalho, propriedade privada e dinheiro, dinheiro e o ser humano, como a abolição da separação entre o ser humano e ele mesmo. Dessa forma, irá concluir o autor: "Eles têm, por isto, como um ideal um sistema bancário organizado, mas esta supressão da alienação, este retorno do homem a si mesmo e aos outros homens, não passa de ilusão. Trata-se de uma autoalienação, uma desumanização tanto mais infame e tanto mais extrema na medida em que seu elemento não é mais a mercadoria, o metal, o papel, mas a existência moral, a existência social, o íntimo do coração humano - sob a aparência da confiança do homem no homem, é a suprema desconfiança e a alienação total.” (MARX, 2015, p. 204) 
enquanto forma abstrata da riqueza" (2013, pp. 52-4). Desse modo, o dinheiro reduz todo o movimento do ser à sua abstração e a um ser quantitativo, reduzindo as carências do ser humano apenas àquelas fisiológicas - agora medidas quantitativamente e realizadas apenas pela posse do dinheiro. Ainda segundo Daniel Bensaïd, posteriormente Marx e Freud serão responsáveis por transformar o sentido do conceito de "fetichismo", deixando de ser um conceito etnológico (e racista ${ }^{11}$ ) e passando a assumir um conteúdo social e psicologicamente críticos, respectivamente.

No segundo capítulo do primeiro manuscrito, denominado "Lucro do capital" (Profit des Kapitals), Karl Marx confronta o conceito de capital de Adam Smith enquanto "trabalho armazenado". Em Smith esta ideia de trabalho acumulado e capital estava relacionada diretamente à noção de geração de riqueza de uma nação à generalização das relações de produção capitalistas e do trabalho assalariado como produtor de riqueza. Para Marx, por sua vez, os teóricos da economia política escondiam que, de fato, o capital se tratava da "propriedade privada dos produtos do trabalho alheio" (MARX, 2010a, p. 39). Ainda diferente daquele conceito de capital como valor que se valoriza de seu pensamento posterior, é importante destacar que para Marx já irá aparecer um processo de abstração que domina a atividade de trabalho e de produção da sociedade. Nessa perspectiva, a economia política enquanto ciência, vai aparecer como uma "guerra de conquista" (MARX, 2010a, p. 37) dos interesses econômicos na sociedade burguesa, sendo ela mesma voltada para a posse e concentração da riqueza em uma classe social particular e não para a distribuição e produção da felicidade dos seres humanos.

Mesmo com essas questões, definitivamente um dos pontos que tornam as concepções econômicas do jovem Marx bastante frágeis é a sua falta de noção sobre os fenômenos do valor e do mais-valor - que ele até admite logo no início de seus cadernos de estudos ${ }^{12}$. Esta debilidade levará o autor a tratar

${ }^{11}$ Sobre a origem do termo "fetichismo", explica Daniel Bensaï: "Inspirado no português (feitiço - fabricado, artificial), a introdução do termo 'fetichismo' no vocabulário do conhecimento social é geralmente atribuído a Balthazar Bekker, autor, em 1691, do Mundo encantado, no qual desenvolve uma análise comparada das velhas religiões pagãs e das religiões dos 'selvagens'; e também, sobretudo, ao livro de Charles de Brosses, Do culto dos deuses fetiches, aparecido em 1760 . O termo evoca, neste caso, uma religião simbolicamente pobre. Para de Brosses, presidente da Assembleia de Dijon, todos os povos podem progredir da mesma maneira, mas encontramos nos negros africanos o culto de certos objetos materiais, chamados fetiches que 'eu chamaria de fetichismo'. Este fetichismo é, na sua opinião, o sinal de um arcaísmo em relação a uma linha de progresso que consiste em passar 'dos objetos sensíveis aos conhecimentos abstratos'. Com Marx (que leu de Brosses em 1842) e com Freud, o fetichismo não designa mais um culto primitivo, mas fenômenos sociais ou psíquicos contemporâneos, quer se trate da submissão ao fetichismo da mercadoria, que se trate da perversão sexual que consiste em tomar uma parte pelo todo. Ele deixa de ser um conceito etnológico para se tornar um conceito crítico.” (BENSAÏD, 2013, p. 52)

12 Escreve: "Riqueza. Aqui já se supõe o conceito de valor, conceito que, entretanto, não está ainda analisado." (MARX, 2015, p. 186) 
de maneira análoga - como os economistas vulgares - o "valor" como "preço", assim como confundir a própria relação de "valor" com "excedente de valor" e perder a perspectiva da relação entre o conceito e a produção e acumulação de riqueza. Em parte, a explicação para esse fato pode ser dada: a) pelo fato do jovem ter escolhido ir para a França, onde o desenvolvimento da economia levou à produção de mercadorias de luxo e as relações de produção típicas do período manufatureiro, sem a constituição de fábricas e com relativo alto grau de especialização dos artesãos (o que também pode ajudar a compreender a preferência teórica por Smith e não Ricardo ${ }^{13}$ ); b) bem como a de resquícios idealistas em sua concepção filosófica, na qual a sociedade é tomada como produto da relação sujeito-objeto, mas, ainda, a superação da essência social contraditória, depende da realização do sujeito.

Apesar de avançar consideravelmente em relação aos pensadores póshegelianos, essa falta de noção sobre o valor também comprometia uma análise crítica da economia política, porque nesse, e em outros sentidos, a compreensão marxiana ainda nem mesmo ultrapassava as teorias dos economistas clássicos, vulgares ou mesmo dos socialistas utópicos - deixando evidente que ainda não havia distinguido e apreendido o que havia de racional entre as diferentes tendências da economia política, especialmente o pensamento de Ricardo. Dessa maneira, como iremos novamente constatar através de suas anotações de leitura, ao invés do autor expressar a concepção de que o excedente produzido era fundamentado na contradição entre a produção e a troca, ele irá acompanhar a concepção de Proudhon, para quem existe um "tributo" pago ao proprietário privado, ao mesmo tempo que também afirmará que "os salários constituem um desconto que a terra e o capital permitem ao trabalhador, uma concessão feita pelo produto do trabalho ao trabalhador" (MARX, 2015, p. 189).

\section{A questão da alienação e sua relação com a economia política}

A partir do último capítulo do primeiro manuscrito é que o jovem Karl Marx vai revelar o núcleo na sua análise da economia política, permitindo que se perceba qual noção ocupa o lugar dos conceitos de valor e do excedente de valor: a divisão do trabalho, que leva ao trabalho assalariado, e por sua vez, consolida historicamente o fenômeno da alienação [Entfremdung]. O fenômeno da alienação, de interpretação hegeliana, no geral, é tomado no interior do processo de experimentação da consciência de si mesma, que se percebe a partir de um outro, colocando-o como objeto e estabelecendo uma

13 O que também deve ser levado em consideração em relação aos estudos de Marx sobre Ricardo no ano de 1844 é, que além de ter aparentemente abordado as questões econômicas colocadas pelo mesmo de maneira fragmentária, ele também utilizou uma edição da obra ricardiana comentada por Say. 
relação sujeito-objeto. Pela necessidade da identidade entre essência do sujeito e do objeto para o processo cognoscente, o trabalho será a atividade propriamente humana que será capaz de mediar o reconhecimento entre a objetivação do sujeito e a subjetividade do objeto. Hegel postulará a necessidade desses momentos, de uma primeira negação e de uma negação desta, enquanto a experimentação racional da consciência de si mesma, visando o percurso da constituição da consciência do senso-comum enquanto consciência-de-si, ou seja, sujeito do processo de conhecimento científico.

O conceito de alienação, assim, não era uma elaboração do próprio Marx, mas sim já havia sido desenvolvido em diferentes sentidos por Hegel, Schelling14 e Feuerbach, de modo que este último o havia influenciado mais diretamente nos últimos meses através de $A$ essência do cristianismo - sendo também importante lembrar que além do acesso às obras de Hegel, o velho Schelling foi professor do jovem autor em Berlim e por isso é provável que tenha tido contato com suas ideias filosóficas. Contudo, com os manuscritos econômico-filosóficos marxianos, pela primeira vez a alienação adquire "um conteúdo socioeconômico aprofundado" (MANDEL, 1968, pp. 30-1), estando enraizada em sua concepção feuerbachiana que privilegiava e partia da sensibilidade, mas, ao mesmo tempo, adquirindo um conteúdo inédito.

É importante notar que, para Marx, o conceito de alienação vai estar ligado à externalização da essência do ser, que por sua vez, na sociedade capitalista, estará diretamente relacionado à atividade de trabalho dos

${ }^{14}$ Em relação a Schelling e sua função no contexto histórico, esclarece Benedicto Sampaio e Celso Frederico: "Pelo mesmo motivo - a insegurança dialética desse núcleo conceitual da realidade -, a monarquia prussiana acabou por retirar o seu apoio semioficial ao pensamento de Hegel. Em 1841 o rei convidou Schelling para preencher a cátedra de Hegel em Berlim, vaga desde a sua morte, Schelling, nesse período, entendia a história como epifania, como manifestação relevadora de Deus, e este como o fundamento da realidade. Desse modo, o estado racional passou a ser substituído, no plano teórico, pelo estado teológico de investidura divina. Com sua autoridade e prestígio, o velho Schelling deveria opor-se à influência crescente dos jovens hegelianos. Significativamente, ele defendia há vários anos um conceito de realidade que denominava 'empírico-superior', que consistia na recusa de toda e qualquer fundamentação racional que escapasse à experiência religiosa da revelação: 'fica sempre, no fundo, o irregular, o não sujeito a normas (...) (que é) nas coisas, a base inapreensível da realidade (...) algo que não é possível reduzir ao entendimento'. Para o velho Schelling, o real não podia ser reduzido ao desenvolvimento racional, e isso, com certeza, reassegurava a confiança da monarquia conservadora na fidelidade permanente dos súditos. Os cursos de Schelling foram frequentados por Engels e Kierkegaard, como a representarem as duas vertentes dissidentes do pensamento de Hegel: a da crítica ateia à teologização da razão e da realidade, e a da crítica religiosa contra a sujeição de Deus à razão e, por conseguinte, contra a racionalização da chamada realidade primeira. O pensamento filosófico da época iria, portanto, cindir-se em torno da questão da natureza, do substrato autopropulsor, da realidade na filosofia de Hegel. As divergências se centralizariam nas teorias a respeito de Deus e do estado. Foi justamente nos termos dessa discussão que Marx se baseou, na busca da autonomia doutrinária, sua proposta de um desdobramento racional ativo do futuro, contraditoriamente, por meio de uma filosofia crítica, a de Feuerbach, que se dispunha antes à contemplação passiva do mundo do que à sua modificação ativa." (SAMPAIO; FREDERICO, 2009, pp. 22-3) 
trabalhadores modernos. Nesse sentido, a essência desses indivíduos se objetiva nos produtos e mercadorias através da atividade de trabalho - que a concepção marxiana avança sobre a de Feuerbach e a entende como a atividade genérica do ser humano, se aproximando de Hegel -, fazendo do próprio objeto uma parte da essência humana e, portanto, algo no qual o conjunto dos trabalhadores deveriam se reconhecer. Contudo, não é o que o jovem Karl Marx está presenciando ao analisar as relações sociais capitalistas, pelo contrário: com a alienação na relação sujeito-objeto da produção industrial capitalista, a sociedade passa a ser enriquecida ao ser povoada e mediada com produtos da atividade de trabalho alienado, mas, contraditoriamente, os trabalhadores se tornam cada vez mais espiritualmente embrutecidos e miseráveis ao serem dominados pelo sistema de assalariamento. Eis que a alienação de influência feuerbachiana, então, vai se tratar de uma separação, cisão, entre a essência e o sujeito, entre o trabalho como autoprodução humana e o trabalho como meio de manutenção da existência física dos indivíduos.

No capítulo “Trabalho alienado" [Die entfremdete Arbeit] Marx começa afirmando que até ali havia admitido os pressupostos da economia política, reivindicando agora o fato de que seus teóricos simplesmente partem da propriedade privada, mas não explicam seu processo de surgimento ${ }^{15}$, desenvolvimento e consolidação, ou melhor, não explicam o porquê suas concepções econômicas são expressões de um desenvolvimento histórico necessário. Será a partir dessa reivindicação, então, que será possível apreender o estatuto da economia política nos manuscritos produzidos em Paris em paralelo com a separação entre a essência e o sujeito: a economia política apenas toma [fassen] o processo social baseado na propriedade privada mas não o compreende [begreifen], e portanto, a economia política é tomada como uma ciência positiva e descritiva que carece do momento dialético ${ }^{16}$, não compreendendo que quanto mais a sociedade capitalista enriquece, na mesma proporção, mais o trabalhador se torna deformado e brutalizado.

A partir da crítica de que a economia política apenas concebeu os aspectos acidentais e não o movimento real e necessário das formas de propriedade, o jovem Marx vai ampliar essa noção ao se contrapor à noção de

\footnotetext{
${ }^{15}$ Questão que já apareceu no artigo de Friedrich Engels publicado nos Anais Franco-Alemães e intitulado Umrisse zu einer Kritik der Nationalökonomie (Esboço para uma crítica da economia política).

${ }^{16}$ No sentido que concebe Hegel no §81 da Enciclopédia das ciências filosóficas: "A dialética, ao contrário [da reflexão], é esse ultrapassar imanente, em que a unilateralidade, a limitação das determinações do entendimento é exposta como ela é, isto é, como sua negação. Todo o finito é isto; suprassumir-se a si mesmo. $O$ dialético constitui pois a alma motriz do progredir científico; e é o único princípio pelo qual entram no conteúdo da ciência a conexão e a necessidade imanentes, assim como, no dialético em geral, reside a verdadeira elevação - não exterior - sobre o finito.” (HEGEL, 2012, p. 163, acréscimo nosso)
} 
generalização de "um estado primitivo imaginário" - tendo em mente diretamente Adam Smith e parte significativa da tradição filosófica iluminista ${ }^{17}$. Nesses marcos, o autor vai chegar a tangenciar sua própria concepção materialista posterior e o conceito de "relações de produção", ao afirmar que "a economia política oculta o estranhamento na essência do trabalho porque não considera a relação imediata entre o trabalhador $e$ a produção" (MARX, 2010a, p. 80) (grifo nosso), até concluir que "se portanto perguntamos: qual a relação essencial do trabalho, então perguntamos pela relação do trabalhador com a produção" (MARX, 2010a, p. 82). Sobre o avanço até esse limite, o jovem também chega a tentar explicar as relações de produção entre o proletariado e os capitalistas, escreve:

Através do trabalho alienado o homem engendra, portanto, não apenas sua relação com o objeto e o ato de produção enquanto homem que lhe são estranhos e inimigos; ele engendra também a relação na qual outros homens estão para a sua produção e o seu produto, e relação na qual ele está para com estes outros homens. Assim como ele [engendra] a sua própria produção para a sua desefetivação, para o seu castigo, assim como [engendra] o seu próprio produto para a perda, um produto não pertencente a ele, ele engendra também o domínio de quem não produz sobre a produção e sobre o produto. Tal como estranha de si a sua própria atividade, ele apropria para o alheio [Fremde] a atividade não própria deste. Consideramos até agora a relação apenas sob o aspecto do trabalhador. Considerá-la-emos, mais tarde, também sob o aspecto do não trabalhador. Através do trabalho alienado, exteriorizado, o trabalhador engendra, portanto, a relação de alguém alheio ao trabalho - do homem situado fora dele - com este trabalho. A relação do trabalhador com o trabalho engendra a relação do capitalista (ou como se queira nomear o senhor do trabalho) com o trabalho. (MARX, 2010a, p. 87)

17 Como boa parte das concepções do direito natural, que entendem o surgimento da propriedade de maneira "imaginária". Como por exemplo, vemos a concepção romântica de Rousseau: "Da cultura de terras resultou necessariamente a sua partilha e, da propriedade, uma vez reconhecida, as primeiras regras de justiça, pois, para dar a cada um o que é seu, é preciso que cada um possua alguma coisa; além disso, começando os homens a alongar suas vistas até o futuro e tendo todos a noção de possuírem algum bem passível de perda, nenhum deixou de temer a represália dos danos que poderia causar a outrem. Essa origem mostra-se ainda mais natural, por ser impossível conceber a ideia da propriedade nascendo de algo que não a mão-de-obra, pois não se compreende como, para apropriar-se de coisas que não produziu, o homem nisso conseguiu pôr mais do que seu trabalho." (ROUSSEAU, 1983, p. 266) Ainda, também poderia destacar parte dos liberais contratualistas, como John Locke, para quem a propriedade privada é um produto do trabalho: "De tudo isso, é evidente que, embora a natureza tudo nos ofereça em comum, o homem, sendo o senhor de si próprio e proprietário de sua pessoa e das ações ou do trabalho que executa, teria ainda em si mesmo a base da propriedade (...). Assim o trabalho, no começo, proporcionou o direito à propriedade sempre que qualquer pessoa achou conveniente empregá-lo sobre o que era comum, que constituiu durante muito tempo a maior parte e ainda é hoje mais do que os homens podem utilizar." (LOCKE, 1978, pp. 51-2) 
Já em relação ao conceito de alienação, este é central para compreender a noção de sujeito sensível humanista de Karl Marx e sua relação com a produção social, que nesse momento ainda estava ligado à concepção feuerbachiana. Feuerbach, por sua vez, também era tributário dos princípios filosóficos da antropologia hegeliana ${ }^{18}$, onde o ser humano forma a si mesmo - percepção esta que já havia sido relacionada e analisada segundo as questões da economia política e do trabalho por Hegel, mas não por Feuerbach. Assim, como já ressaltamos, nesse momento a noção de trabalho marxiana não passará pelas relações com o valor como serão apresentadas em O capital, mas sim será fundamentada na noção de divisão social do trabalho de influência smithiana, que o leva a confundir e entender essa divisão como essencialmente pejorativa e deletéria à atividade de trabalho e ao trabalhador.

Desse modo, apesar de suas debilidades, a retomada e o desdobramento do conceito feuerbachiano de alienação pelo jovem Marx foi importante: a) porque "a crítica da alienação religiosa se aprofunda tornando-se crítica da alienação social” (BENSAÏD, 2013, p. 50), ou seja, a crítica social passa a entender a autoprodução da consciência do sujeito como uma produção conjunta à própria sociedade; b) assim como, e buscamos deixar isso bem claro, a retomada e reaproximação das questões da economia política com a dialética hegeliana, que inaugura a abertura para a análise das questões sobre em que medida é possível analisar o modo de produzir de uma sociedade e encontrar as causas de seu desenvolvimento lógico e histórico, bem como suas formas de manifestação de consciência de si, jurídica, política, estética e artística etc.

O fenômeno da alienação para Marx em 1844, dessa maneira, implica em um movimento duplo para o sujeito: por um lado ele é um "estranhamento" [Entäusserung], e por isso implica em uma exteriorização, uma despossessão, que produz riqueza; por outro ele também é uma “alienação” [Entfremdung] e portanto um alhear-se, onde ao invés de efetivar através de se realizar pelo reconhecimento e negação do outro, ele se desefetiva na medida em que o

18 Essa antropologia hegeliana, nos Manuscritos econômico-filosóficos, aparece principalmente como autoatividade, que ao se tornar abstrata, perde seu caráter formador [Bildung] e reconciliador do ser humano consigo mesmo: “A grandeza da Fenomenologia hegeliana e de seu resultado final - a dialética, a negatividade enquanto princípio motor e gerador - é que Hegel toma, por um lado, a autoprodução do homem como um processo, a objetivação como desobjetivação, como exteriorização [despossessão] [Entäusserung] e suprassunção dessa exteriorização; é que compreende a essência do trabalho e concebe o homem objetivo, verdadeiro, porque homem efetivo, como o resultado de seu próprio trabalho. O comportamento efetivo, ativo do homem para consigo mesmo na condição de ser genérico, ou o acionamento de seu [ser genérico] enquanto um ser genérico efetivo, isto é, na condição ser humano, somente é possível porque ele efetivamente expõe todas as suas forças genéricas - o que é possível apenas mediante a ação conjunta dos homens, somente enquanto resultado da história -, comportando-se diante delas como frente a objetos, o que, por sua vez, só em princípio é possível na forma da alienação.” (MARX, 2010a, p. 123, acréscimo nosso) 
outro não é apreendido como um produto de sua vontade. Nessa concepção, o mérito se encontra na distinção e relação da unidade do fenômeno, o sujeito, com as determinações materiais das relações sociais do trabalho enquanto atividade efetiva de produção de riqueza e atividade abstrata do ser humano. Com a exteriorização e a objetivação através da atividade de trabalho abstrato, assalariado, típica das relações capitalistas, o mundo exterior se torna cada vez mais povoado de objetos autônomos e independentes (mercadorias e riqueza) da vontade e das carências humanas. Nessa linha, o ser humano se desumaniza à medida em que se efetiva no mundo. Diz o autor:

Nós partimos de um fato nacional-econômico, presente. $\mathrm{O}$ trabalhador se torna tanto mais pobre quanto mais riqueza produz, quanto mais a sua produção aumenta em poder e extensão. O trabalhador se torna uma mercadoria tão mais barata quanto mais mercadorias cria. Com a valorização do mundo das coisas aumenta em proporção direta a desvalorização do mundo dos homens. $\mathrm{O}$ trabalho não produz somente mercadorias; ele produz a si mesmo e ao trabalhador como uma mercadoria, e isto na medida em que produz, de fato, mercadorias em geral. Este fato nada mais exprime, senão: o objeto que o trabalho produz, o seu produto, se lhe defronta como um ser estranho, como um poder independente do produtor. O produto do trabalho é o trabalho que se fixou num objeto, fez-se coisa, é a objetivação do trabalho. A efetivação do trabalho é a sua objetivação. Esta efetivação do trabalho aparece ao estado nacionaleconômico como desefetivação do trabalhador, a objetivação como perda do objeto e servidão ao objeto, a apropriação como alienação, como estranhamento. (...) A objetivação tanto aparece como perda do objeto que o trabalhador é despojado dos objetos mais necessários não somente à vida, mas também dos objetos do trabalho. Sim, o trabalho mesmo se torna um objeto, do qual o trabalhador só pode se apossar com os maiores esforços e com as mais extraordinárias interrupções. A apropriação do objeto tanto aparece como alienação que, quanto mais objetos o trabalhador produz, tanto menos pode possuir tanto mais fica sob o domínio do seu produto, do capital. (...) A despossessão [Entäusserung] do trabalhador em seu produto tem o significado não somente de que seu trabalho se torna um objeto, uma existência externa, mas, bem além disso, [que se torna uma existência] que existe fora dele, independente dele e estranha a ele, tornando-se uma potência autônoma diante dele, que a vida que ele concedeu ao objeto se lhe defronta hostil e estranha. (MARX, 2010a, pp. 80-1)

A partir dessa exposição, Karl Marx chega a um dos pontos altos dos Manuscritos, apresentando (e retomando) uma série de questões que buscavam servir de instrumento e armas contra as tendências filosóficas e políticas que atuavam no período - desde os jovens hegelianos (Max Stirner principalmente), os economistas políticos vulgares, passando pelos herdeiros dos socialistas utópicos e, em menor peso, por Proudhon. Se entre os debates 
com os jovens hegelianos a crítica aos "socialistas altruístas" dos "Livres de Berlim” havia sido significativamente bem-sucedida, com a produção dos Manuscritos econômico-filosóficos, ainda que não publicados, Marx passa a conseguir fundamentar - de maneira incipiente, mas já assentada - as questões da economia política em relação à vida produtiva, como aquela que é capaz de representar a estrutura da vida genérica, da essência humana. Ou em outros termos, ainda não utilizados nos manuscritos, para o autor em 1844 as relações de produção sociais guardam as formas e os padrões de reprodução social, escreve:

Pois primeiramente o trabalho, a atividade vital, a vida produtiva mesma aparece ao homem apenas como um meio para a satisfação de uma carência, a necessidade de manutenção da existência física. A vida produtiva é, porém, a vida genérica. É a vida engendradora de vida. No modo da atividade vital encontra-se o caráter inteiro de uma species, seu caráter genérico, e a atividade consciente livre é o caráter genérico do homem. A vida mesma aparece só como meio de vida. (...) $\mathrm{O}$ trabalho alienado inverte a relação a tal ponto que o homem, precisamente porque é um ser consciente, faz da sua atividade vital, da sua essência, apenas um meio para sua existência. (MARX, 2010a, pp. 84-5)

Na concepção de Marx - influenciado pela dialética da dominação e servidão da Fenomenologia do Espírito de Hegel, mas ressaltando e delimitando, ao mesmo tempo, a generalidade, as particularidades e singularidades das modernas lutas de reconhecimento das sociedades europeias ocidentais como historicamente específicas e relativas à ascensão e consolidação do conjunto da sociedade capitalista, será com o fenômeno da alienação que se produzirá o processo de abstração da atividade do trabalho humano, onde o ser humano não mais realiza a negação ao se colocar como objeto de si mesmo, pois agora este é despossuído através da apropriação dos meios de trabalho e do produto de sua atividade de trabalho que se tornam riqueza privada acumulada. A realização do conjunto social da atividade de trabalho alienado e da autonomia econômica da sociedade burguesa, desse modo, para Marx, estaria em contradição com a realização de uma sociabilidade fundamentada e que visa a liberdade e a justiça.

Mesmo tendo muitos pontos e concepções econômicas atrasadas em relação à escola clássica, os economistas vulgares e os socialistas utópicos, portanto, o jovem autor consegue, por outro lado, produzir um importante salto qualitativo ao concluir que a classe trabalhadora moderna, o proletariado, não tem meios para se defrontar consigo mesmo ao encarar o mundo moderno povoado de produtos do trabalho humano. A questão central para Marx, então, era a de humanizar o proletariado, o tornar sujeito, através de uma abolição da atividade de trabalho alienado e da propriedade privada. 
Para o jovem em 1844, a elaboração filosófica tomada desde Feuerbach e dirigida politicamente por Hess, representava uma denúncia radical não somente do sistema filosófico de G. W. F. Hegel, como também da essência da sociedade capitalista e seus teóricos da economia política, uma vez que esta possuía sua sociabilidade alienada por também ser produzida a partir de uma atividade alienada. Mesmo com limites e sem apreender alguns elementos econômicos fundamentais, o jovem Marx, baseado em uma interpretação da figura de dominação e servidão hegeliana, já foi capaz de perceber algumas determinações das relações de produção capitalistas e defender uma via emancipatória baseada em uma revolução da classe trabalhadora moderna e na superação do trabalho alienado. Diferenciando-se de Hegel - ainda que a aproximação da economia política e a busca por superar uma "concepção dicotômica do ser" (NOVELLI, 1998, p. 297) o tivesse o aproximado do mesmo -, Marx pensava do interior da figura da servidão e dominação e denunciava a impossibilidade do reconhecimento recíproco ${ }^{19}$ da consciência servil enquanto verdade da consciência senhorial como solução específica para a sociedade capitalista.

Para a interpretação marxiana, Hegel havia apreendido a lógica das lutas de reconhecimento das sociedades ocidentais desde a polis grega até as constituições das nações modernas, mas não conheceu profundamente a particularidade histórica da essência contraditória da sociedade civil burguesa e se equivocou em seu diagnóstico. Marx interpretará, então, a filosofia hegeliana como uma mera expressão abstrata e lógica do movimento da história, reforçando a posição da superação da dicotomia entre ser e pensar, entre prática do pensamento e pensamento da prática, como fundamento para

19 Segundo a interpretação de Henrique C. Lima Vaz da dialética da dominação e servidão de Hegel: "A articulação dos silogismos ou da dialética do Senhorio e da Servidão do ponto de vista do Escravo irá reabrir o caminho para o reconhecimento efetivo e recíproco que se mostra inviável a partir da consciência ociosa do Senhor. Hegel dá às formas de mediação que unem dialeticamente a consciência servil ao Senhor e ao mundo a denominação geral de 'ação de formar-se' [das Formieren] ou cultura. O mundo trabalhado é, com efeito, mediador para o Escravo na sua relação com o Senhor mas aqui o trabalho, sob a forma social do serviço, irá formar a consciência servil, pela retenção do desejo, para uma relação verdadeiramente humana com o mundo. Irá, pois fazê-la retornar a si mesma como consciência-de-si. Tendo experimentado o temor e o tremor diante do Senhor absoluto - a Morte - e conservado, assim, o seu ser, a consciência servil entra agora para a escola da sabedoria. (...) O temor diante da morte, a disciplina do serviço em face do Senhor e a atividade laboriosa exercida sobre o mundo são, assim, para a consciência servil o caminho da negação seja do ser-reconhecido unilateral do Senhor que tem agora o seu efetivo ser-para-si num outro, seja do seu próprio não-reconhecimento que é suprimido pela cultura. Esta faz passar o simples ser do Escravo (conservado no temor da morte e no serviço do Senhor) para o ser-para-si independente que se constitui pelo agir transformador do mundo. A dialética do Senhorio e da Servidão faz, desta sorte, surgir a figura da liberdade da consciência-de-si como verdade da certeza que ela tem de si mesma: uma verdade que passa do sujeito ao mundo pela atividade da cultura. (...) Esse saber deve apresentar-se como fundamento para a exigência histórica de uma sociedade do reconhecimento universal." (VAZ, 1981, pp. 22-3) 
a ação política desalienada e humanizadora. Nesses marcos, o jovem autor buscará, então, distinguir quatro aspectos do fenômeno de alienação da atividade de trabalho que desumanizam e deformam o ser humano, em particular o proletariado.

1) o primeiro é na "exteriorização" da essência do trabalhador e sua relação com os produtos de sua atividade de trabalho, que faz de sua existência mero predicado da produção de mercadorias:

A exteriorização [Entäusserung] do trabalhador em seu produto tem o significado não somente de que seu trabalho se torna um objeto, uma existência externa, mas, bem além disso, [que se torna uma existência] que existe fora dele, independente dele e estranha a ele, tornando-se uma potência autônoma diante dele, que a vida que ele concedeu ao objeto se lhe defronta hostil e estranha. (...) Quanto mais, portanto, o trabalhador se apropria do mundo externo, da natureza sensível, por meio de seu trabalho, tanto mais ele se priva dos meios de vida segundo um duplo sentido: primeiro, que sempre mais o mundo exterior sensível deixa de ser um objeto pertencente ao seu trabalho, um meio de vida do seu trabalho; segundo, que [o mundo exterior sensível] cessa, cada vez mais, de ser meio de vida no sentido imediato, meio para a subsistência física do trabalhador. Segundo este duplo sentido, o trabalhador se torna, portanto, um servo do seu objeto. (MARX, 2010a, p. 81)

2) o segundo momento, manifesta-se "dentro da própria atividade produtiva”, no próprio ato da produção, como "trabalho obrigatório", forçado e de autossacrifício:

Mas a alienação não se mostra somente no resultado, mas também, e principalmente, no ato da produção, dentro da própria atividade produtiva. Como poderia o trabalhador defrontar-se alheio ao produto da sua atividade se no ato mesmo da produção ele não se alienasse a si mesmo? Na alienação do objeto do trabalho resume-se somente a alienação, a exteriorização [despossessão] na atividade do trabalho mesmo. Em que consiste, então, a exteriorização do trabalho? Primeiro, que o trabalho é externo ao trabalhador, isto é, não pertence ao seu ser, que ele não se afirma, portanto, em seu trabalho, mas nega-se nele, que não se sente bem, mas infeliz, que não desenvolve nenhuma energia física e espiritual livre, mas mortifica sua physis e arruína o seu espírito. O trabalhador só se sente, por conseguinte e em primeiro lugar, junto a si [quando] fora do trabalho e fora de si [quando] no trabalho. Está em casa quando não trabalha e, quando trabalha, não está em casa. O se trabalho não é, portanto, voluntário, mas forçado, trabalho obrigatório. O trabalho não é, por isso, a satisfação de uma carência, mas somente um meio para satisfazer necessidades fora dele. Sua estranheza [Fremdheit] evidencia-se aqui [de forma] tão pura que, tão logo inexista coerção física ou outra qualquer, foge-se do trabalho como de uma peste. $O$ trabalho externo, o trabalho no qual o homem se exterioriza, é um trabalho de autossacrifício, de mortificação. 
Finalmente, a externalidade do trabalho aparece para o trabalhador como se [o trabalho] não fosse seu próprio, mas de um outro, como se [o trabalho] não lhe pertencesse, como se ele no trabalho não pertencesse a si mesmo, mas a um outro. (MARX, 2010a, pp. 82-3, acréscimo nosso)

3) O terceiro momento da alienação do trabalho, segundo o jovem Marx, vai aparecer na alienação-de-si, de seu ser genérico, de sua essência, e consequentemente, da própria natureza:

A energia espiritual e física própria do trabalhador, a sua vida pessoal - pois o que é vida senão atividade - como uma atividade voltada contra ele mesmo, independente dele, não pertence a ele. A alienação-de-si, tal qual acima a alienação da coisa. Temos agora ainda uma terceira determinação do trabalho alienado a extrair das duas vistas até aqui. $\mathrm{O}$ homem é um ser genérico, não somente quando prática e teoricamente faz do gênero, tanto do seu próprio quanto do restante das coisas, o seu objeto, mas também - e isto é somente uma outra expressão da mesma coisa - quando se relaciona consigo mesmo como [com] o gênero vivo, presente, quando se relaciona consigo mesmo como [com] um ser universal, [e] por isso livre. A vida genérica, tanto no homem quanto no animal, consiste fisicamente, em primeiro lugar, nisto: que o homem (tal qual o animal) vive da natureza inorgânica, e quanto mais universal o homem [é] do que o animal, tanto mais universal é o domínio da natureza inorgânica da qual ele vive. Assim como plantas, animais, pedras, ar, luz etc., formam teoricamente uma parte da consciência humana, em parte como objetos da ciência natural, em parte como objetos da arte - sua natureza inorgânica, meios de vida espirituais, que ele tem de preparar prioritariamente para a fruição e para a digestão -, formam também praticamente uma parte da vida humana e da atividade humana. (MARX, 2010a, pp. 83-4)

4) Por fim, o último momento é a alienação do ser humano pelo próprio ser humano, ou seja, o próprio gênero e essência humana tornam apenas um meio para garantir a existência dos indivíduos:

O engendramento prático de um mundo objetivo, a elaboração da natureza inorgânica é a prova do homem enquanto um ser genérico consciente, isto é, um ser que se relaciona com o gênero enquanto sua própria essência ou [se relaciona] consigo enquanto ser genérico. (...) $\mathrm{O}$ animal forma apenas segundo a medida e a carência da species à qual pertence, enquanto o homem sabe produzir segundo a medida de qualquer species, e sabe considerar, por toda a parte, a medida inerente ao objeto; o homem também forma, por isso, segundo as leis da beleza. Precisamente por isso, na elaboração do mundo objetivo [é que] o homem se confirma, primeiro lugar e efetivamente, como ser genérico. Esta produção é a sua vida genérica operativa. Através dela a natureza aparece como a sua obra e a sua efetividade. O objeto do trabalho é portanto a objetivação da vida genérica do homem: quando o homem se duplica não apenas na consciência, intelectual[mente], mas operativa, efetiva[mente], 
contemplando-se, por isso, a si mesmo num mundo criado por ele. Consequentemente, quando arranca do homem o objeto de sua produção, o trabalho alienado arranca-lhe sua vida genérica, sua efetiva objetividade genérica e transforma a sua vantagem com relação ao animal na desvantagem de lhe ser tirado o seu corpo inorgânico, a natureza. Igualmente, quando o trabalho alienado reduz a autoatividade, a atividade livre, a um meio, ele faz da vida genérica do homem um meio de sua existência física. A consciência que o homem tem do seu gênero se transforma, portanto, mediante a alienação, de forma que a vida genérica se torna para ele um meio. (...) uma consequência imediata disto, de o homem estar estranhado do produto do seu trabalho, de sua atividade vital e de seu ser genérico é a alienação do homem pelo [próprio] homem. Quando o homem está frente a si mesmo, defronta-se com ele o outro homem. O que é produto da relação do homem com seu trabalho, produto de seu trabalho e consigo mesmo, vale como relação do homem com outro homem, como o trabalho e o objeto do trabalho de outro homem. Em geral, a questão de que o homem está alienado do seu ser genérico quer dizer que um homem está alienado do outro, assim como cada um deles [está alienado] da essência humana. O estranhamento do homem, em geral toda a relação na qual o homem está diante de si mesmo, é primeiramente efetivado, se expressa, na relação em que o homem está para com o outro homem. Na relação do trabalho alienado cada homem considera, portanto, o outro segundo o critério e a relação na qual ele mesmo se encontra como trabalhador. (MARX, 2010a, pp. 85-6)

Dessa maneira, no mesmo capítulo, o jovem Marx ainda vai concluir que o trabalho alienado e a propriedade privada, com força de necessidade lógica, se engendrarão historicamente de forma mútua. Eis aqui, então, uma noção ainda germinal do autor, mas que já apreende o núcleo do surgimento e consolidação histórica da propriedade privada: será através da apropriação e acumulação privada dos meios de produção, produtos e do excedente produtivo, bem como da própria atividade de trabalho alienado, que a propriedade privada será consolidada. Desse modo, a atividade de trabalho alienado avançará ao ponto de ser compreendida como um processo histórico de expropriação dos instrumentos da atividade de trabalho e que adquire uma forma social permanente, ou melhor, adquire a particularidade das relações de produção entre sujeitos sociais específicos, ao mesmo tempo que põe uma forma de riqueza e a sociabilidade abstrata efetivas (MARX, 2010a, p. 87).

\section{A crítica da dialética hegeliana de Karl Marx em 1844}

O capítulo em que Marx trata diretamente da dialética hegeliana, denominado "Crítica da dialética e da filosofia hegelianas em geral", do ponto de vista filosófico, é central para a análise e conhecimento dos debates presentes nos Manuscritos econômico-filosóficos produzidos em 1844. Nele, 
ficam evidentes as primeiras críticas e os primeiros nuances da tentativa do autor de romper com os princípios assumidos e nos quais também estavam limitados o movimento jovem hegeliano. Contudo, apesar das críticas acertadas, o próprio Karl permanecia fundamentado e dependente da filosofia de Hegel, estabelecendo uma relação contraditória em relação ao mestre e aos herdeiros jovem hegelianos - em que, ainda que não superasse completamente o mestre, ao retomar o tema da economia política pôde se tornar aquele que estava mais próximo de uma "filosofia do trabalho" no sentido desenvolvido por Hegel. Nesse ponto, inclusive, é preciso destacar que embora relação entre Hegel e Marx seja complexa, ela também se caracteriza por uma complementariedade, de modo que entre eles "não há continuísmo, há sim continuidade" que "não se reduzem numa identidade ou diferença absolutas" (NOVELLI, 1998, p. 315).

Desse modo, o próprio jovem autor considera um balanço filosófico e político como fundamental para os jovens hegelianos: afinal, qual a posição ontológica que assumiam, ou melhor, "o que fazer diante da dialética hegeliana?” (MARX, 2010a, p. 115). Essa pergunta não era meramente retórica, ainda que sua crítica à mera reprodução dos princípios e da linguagem de Hegel respingasse nas suas próprias concepções filosóficas de 1844. Nesse momento, o jovem ainda assumia uma linguagem neo-hegeliana tomada principalmente de Ludwig Feuerbach, e entendia a crítica deste elaborada desde as Teses provisórias para a reforma da filosofia de 1842, bem como em Princípios da filosofia do futuro de 1843, como a fundamentação filosófica do ateísmo, que era, por sua vez, o primeiro passo do caminho para aquilo que Marx entendia por comunismo - concepção que mudaria definitivamente a partir de $A$ ideologia alemã.

Após 1845, não apenas a realização do proletariado enquanto sujeito será modificada, como a totalidade da relação sujeito-objeto - e que Marx começará a apresentar o germe desse rompimento nos Manuscritos econômico-filosóficos quando critica a posição dos jovens hegelianos como um todo por suas relações apáticas com a dialética de Hegel. Apesar disso, o próprio jovem Karl Marx também possuía uma relação ambígua com a dialética hegeliana, que, contraditoriamente, o levou a desenvolver uma concepção cada vez mais negativa sobre os fundamentos filosóficos da crítica da economia política à medida que buscava se afastar da própria herança de Hegel. Contudo, nos manuscritos filosóficos e econômicos de 1844 a característica do sujeito marxiano é a de reconciliação do "ser genérico" com sua essência da crítica ontológica de Feuerbach, uma concepção que se distanciava daquela que será responsável por uma nova teoria crítica e revolucionária da sociedade capitalista posterior (MARX, 2010a, p. 117).

Essa posição de Marx em relação a Hegel, então, pode ser demonstrada não apenas nos apontamentos que o jovem autor faz nesse capítulo a respeito 
do mestre, como também pelo desenvolvimento de um pensamento próprio "a partir das categorias hegelianas e [que] permanece no interior delas" (NOVELLI, 1998, p. 315, acréscimo nosso), onde ficam marcadas a aproximação do jovem autor da economia política de Adam Smith e a retomada da concepção hegeliana de trabalho como atividade de autoprodução do ser humano. Nesses marcos, apesar da compreensão do núcleo do sistema filosófico de Hegel - em que se destaca a compreensão da dialética, da "negatividade enquanto princípio motor e gerador" -, a interpretação marxiana de Hegel apontava que existia uma unilateralidade por considerar criticamente apenas o "lado positivo do trabalho, não seu [lado] negativo" (MARX, 2010a, pp. 123; 124).

Com essa crítica de que Hegel havia conhecido apenas o lado positivo do trabalho, Marx a dirigia para a própria metafísica do espírito do mestre, que ao conceber os sujeitos imediatos apenas como mediações do espírito, fazia do sujeito real do trabalho esse espírito e não o ser sensível e concreto. Ao considerar apenas esse lado positivo do trabalho e desconsiderar seu lado negativo, a concepção marxiana interpretava que Hegel havia chegado às portas do materialismo, mas, ao fim e a cabo, cedido aos encantos do idealismo: a solução encontrada para resolver a essência contraditória da sociedade burguesa viria a partir de uma esfera ideal, superior, da astúcia da razão, do trabalho do espírito e do estado. De maneira original, Marx será o primeiro a colocar a pedra de toque de uma crítica da "metafísica" da sociedade civil burguesa e rejeitar a solução da luta pelo reconhecimento através de um estado ideal como produto da produção social alienada.

Desse modo, em 1844, a partir das diferentes concepções de alienação, Marx não via a possibilidade de superação da alienação do ser para-si através do reconhecimento do trabalhador com as mediações produzidas pela sociedade capitalista, senão apenas pela organização revolucionária do proletariado que confrontaria seu outro, a burguesia como sujeito social; enquanto Hegel, ao contrário, não via na organização e atividade revolucionária as condições para estabelecer o ethos social, mas sim na possibilidade do reconhecimento mútuo entre a consciência servil e senhoril através de uma "pedagogia do trabalho" que produziria conscientemente o estado como uma esfera superior e universal que, por sua vez, se reconheceria como produto do trabalho social e garantiria o interesse comum da comunidade ética. Na mesma medida, a sociedade constituída pelo trabalho social humanizado também se reconheceria como produtora do conjunto de leis e da ordem vigente.

Ao interpretar que a concepção de trabalho de Hegel somente era viável na forma de alienação, ou seja, que relegava a realização da essência das relações sociais para uma esfera externa, Marx buscará aprofundar e radicalizar tais questões agora com a vantagem histórica de ter acesso às 
críticas dos socialistas utópicos para a escola clássica de economia política e em oposição aos seus pensadores vulgares - estes últimos, apologistas do capitalismo e que buscavam criminalizar e desmoralizar as nascentes organizações e reivindicações dos trabalhadores. Ainda que não tivesse completa clareza das distintas tendências da economia política e suas relações com as classes sociais, o comunismo de Karl Marx em 1844 poderia ser considerado como uma espécie de "socialismo utópico alemão" que adotava um ponto de vista e soluções que variavam entre os posicionamentos da pequena-burguesia arruinada, dos intelectuais socialistas e do nascente proletariado anterior às revoluções de 1848. Para o jovem, estas frações de classes sociais deveriam se aliar politicamente ao perceber que o capitalismo jogava um contingente cada vez maior de trabalhadores na miséria do assalariamento, e assim buscarem se reconciliar com seu "ser genérico", o sujeito humanista, como forma de superação não apenas da atividade de trabalho alienado, mas também da propriedade privada dos meios de produção.

Este comunismo de 1844, de princípio filosófico e de início da crítica à economia política como uma ciência de enriquecimento e pauperização da sociedade civil burguesa, se trata de um "momento revolucionário" (LÖWY, 2002, p. 145) em que as forças humanas se reconciliariam consigo mesmas através de processos históricos de socialização dos produtos e do excedente da produção social. Para tanto, o fenômeno da despossessão [Entäusserung], que na concepção marxiana Hegel havia tomado como uma mera mediação do trabalho do espírito, se tratava na verdade de uma apropriação material privada dos meios de produção, produtos e excedente, que só poderia ser superada pela "negação da negação"; ou seja, pela negação desse estado de despossessão privada que era tomado como uma primeira negação, do trabalho alienado, efetivando agora a "realização do ser humano" enquanto "sujeito real". Nos artigos de agosto de 1844, publicados na Vorwärts!, no entanto, já é notório que a concepção de comunismo de Marx agora pressupõe, além do proletariado como elemento ativo e capaz de se organizar como classe social, um processo revolucionário de caráter político e social que transforme todo o modo de se produzir a vida.

A posição marxiana de 1844 também é evidenciada, por exemplo, pela sua visão ainda romântica sobre as associações de trabalhadores, que ainda não ganhou a conotação revolucionária e o germe do desenvolvimento histórico de novas relações de produção fundamentadas nos princípios e ideais socialistas. Nos Manuscritos econômico-filosóficos, a noção de associação para Marx vai aparecer, assim, de maneira programática, mas apenas aplicável à forma de propriedade fundiária e às atividades de trabalho na terra, que reconciliariam a relação desalienada e racional entre o ser humano e a 
natureza ${ }^{20}$. Aqui, novamente a escolha de mudança para a França, e suas condições socioeconômicas, eram decisivas para as elaborações do jovem autor, de maneira que as manufaturas e as corporações de ofícios que organizavam os trabalhadores e artesãos franceses eram referenciais avançados em relação a Alemanha, mas atrasados em relação a Inglaterra.

Em relação à dialética no pensamento do jovem Karl Marx, a crítica negativa, sua importância se mostra, além do combate e ruptura em relação ao movimento jovem hegeliano, também para o combate e superação das tendências econômicas que se consolidavam após a década de 1830 notadamente os economistas clássicos, vulgares e os socialistas utópicos. Nesse sentido, a análise dialética permitirá a apreensão das mediações dos processos econômicos em meio aos fenômenos sociais, apreendendo suas particularidades ao mesmo tempo em que evidencia seus aspectos universalizantes - permitindo apreender a essência dos mesmos, e não serem tomados como entes metafísicos, unilaterais e que se fundam fechados em si mesmos. Ao contrário, será o aprimoramento da análise negativa da realidade socioeconômica surgida a partir de 1844 que permitirá a Marx elaborar e correlacionar os conceitos de "forças produtivas", "relações de produção", "ideologia", "modo de produção" e "modo de reprodução" entre 1845-7, e por sua vez, consolidar a ruptura em relação aos jovens hegelianos, Feuerbach e às análises e saídas propostas desde Hegel (RUBIN, 2014, pp. 457-8).

Ainda nesses marcos, será a dialética que fornecerá as bases para a posterior constituição da teoria crítica da sociedade capitalista marxiana como uma superação da economia clássica, da economia vulgar e do socialismo utópico. A partir da consolidação de sua nova filosofia materialista, Marx e Engels começarão a desenvolver os instrumentos teóricos que permitem conhecer o núcleo racional da estrutura de produção e reprodução da sociedade capitalista, desde seus aspectos socioeconômicos quanto das estruturas sociais - jurídicas, políticas, econômicas, estéticas, epistemológicas etc. - como da manifestação das relações abstratas de exploração e dominação entre as classes sociais dominantes e dominadas. Paralelamente, os jovens autores não elaboraram apenas mais uma concepção filosófica e científica para analisar a realidade, mas também passaram a fundamentar teoricamente e ajudar a transformar as próprias relações entre as organizações de

${ }^{20}$ Escreve Marx nos Manuscritos econômico-filosóficos: "A associação, aplicada à terra e ao solo, partilha a vantagem da grande posse fundiária do ponto de vista político-econômico, e realiza primeiramente a tendência originária da divisão, a saber, a igualdade, assim como ela também coloca a ligação afetiva do homem como a terra de um modo racional e não mais [mediado] pela servidão, pela dominação e por uma tola mística da propriedade, quando a terra deixa de ser um objeto de regateio e se torna novamente, mediante o trabalho livre e a livre fruição, uma propriedade verdadeira e pessoal do homem. Uma grande vantagem da divisão é que a sua massa se arruína na propriedade de um outro modo que na indústria, uma massa que não pode mais decidir-se pela servidão.” (MARX, 2010a, p. 76) 
trabalhadores - e consequentemente a própria relação dos trabalhadores entre si -, fazendo com que o conceito de comunismo desde os manuscritos começasse a ser forjado pela práxis desse proletariado moderno.

Em relação a Hegel, nos manuscritos de 1844 Marx adota uma linha expositiva que apresenta sua leitura sobre a filosofia hegeliana - em particular seu princípio antropológico de autoprodução do ser humano, que, para a interpretação marxiana, possuía como mérito a apreensão da atividade de trabalho como objetivação da essência do "ser genérico" e que fundamentava as relações sociais capitalistas. Será, então, no capítulo sobre a dialética hegeliana que o jovem autor explicitará sua discordância em relação ao aspecto idealista do conceito de trabalho formador de Hegel, utilizando-se da crítica dos primeiros socialistas ao processo revolucionário francês ao postular que, no momento da negação em relação ao produto da atividade de trabalho, o trabalhador não possui os meios para superar sua condição dependente e apreender a objetividade das relações sociais, e por isso sua atividade de trabalho é alienada pois serve para produzir riqueza, mas não para a sanar suas próprias carências.

Em 1844 a interpretação feuerbachiana sobre a filosofia de Hegel influenciava Marx, de modo que, para essa interpretação, o ser humano apenas efetivava e confirmava sua essência em sua forma alienada - que o jovem caracterizava e apontava como "a raiz do falso positivismo de Hegel" (MARX, 2010a, p. 130) -, e portanto, não se tratava da "confirmação da verdadeira essência”, do verdadeiro ser humano, mas sim daquele alienado pela atividade de trabalho capitalista. A solução apresentada por Marx para a realização do verdadeiro sujeito, ou melhor, da humanização do ser humano em sua forma alienada pelo trabalho alienado, só poderia vir através de um outro momento que recuperasse e reestruturasse "a universalidade da realidade concreta como conceito” (NOVELLI, 1998, p. 301), ou seja, a negação da negação, que por sua vez realizaria o sujeito real e colocaria as condições da sociedade comunista. Como já ressaltado, o conceito de comunismo marxiano em 1844 passou por uma série de mudanças, contudo já mostrava, por um lado, a força da ascensão das organizações e métodos de luta dos trabalhadores modernos, bem como por outro, o avanço teórico que os primeiros contatos com a economia política permitiram ao jovem no interior do pensamento pós-hegeliano.

Uma vez que existia a compreensão de que para Hegel deveria ser considerada apenas a existência efetiva de uma coisa ou fenômeno enquanto objeto de um saber, mas ao mesmo tempo ele tomava o abstrato como efetivo, o jovem autor também via nesse aspecto da filosofia hegeliana o último subterfúgio da velha metafísica e do "homem religioso" (MARX, 2010a, p. 132) - e portanto, o próprio conteúdo que poderia justificar o aspecto conservador da filosofia hegeliana. Ademais, a crítica do jovem Marx acerca da abstração do "ser" apenas como objeto do pensamento e não como existência sensível 
seguia a trilha da crítica feuerbachiana, debruçando-se sobre os momentos positivos da dialética hegeliana no interior da alienação e apontando como o mestre não havia compreendido a especificidade do trabalho alienado, negativo, na sociedade capitalista. Na dialética especulativa, para Marx, assim, a verdadeira vida é tomada como a abstração, alienação, de modo que o sujeito se manifesta como um resultado meramente metafísico - ou místico como tomava emprestado de Feuerbach.

A consequência dessa concepção por parte de Hegel, segundo Marx, era de que a natureza, o ser humano e a sociedade civil burguesa aparecem como meros predicados de um Deus, um Espírito Absoluto e um estado - de forma que estes sim podem ser considerados como $o$ ser real. Dessa concepção formal e abstrata da atividade de autoprodução do ser humano, o ser real seria considerado apenas como a consciência, a negação, sem conteúdo e como uma expressão meramente abstrata - ou seja, a atividade de autoprodução se tornaria uma simples abstração, negatividade absoluta, que se cristalizaria e se conceberia como autônoma, fundamentadora e formadora de si mesma enquanto atividade. Apesar de chegar aos limites da dialética sujeito-objeto e da antropologia filosófica hegelianas pela sua crítica de viés feuerbachiano, bem como perceber que o núcleo racional da dialética especulativa possibilitava apreender como os conceitos determinados se constituem enquanto formas do pensamento fixas universais - e portanto como consequência lógica e necessária da alienação geral humana -, Marx ainda não ultrapassa tais limites nos Manuscritos econômico-filosóficos. Escreve:

O positivo, que Hegel aqui conseguiu - na sua lógica especulativa , é que os conceitos determinados, as formas de pensamento universais fixas, em sua autonomia diante da natureza e do espírito, são um resultado necessário da alienação universal da essência humana, portanto também do pensar humano, e que Hegel os apresentou e reuniu, por isso, como momentos do processo de abstração. Por exemplo, o ser suprassumido é essência, a essência suprassumida, conceito, o conceito suprassumido... ideia absoluta. Mas o que é então a ideia absoluta? Ela se suprassume novamente a si mesma, se não quer voltar a passar de novo por todo o ato de abstração e contentar-se, assim, em ser uma totalidade de abstrações ou a abstração que a si se apreende. Mas a abstração que se apreende como abstração sabe-se como nada; ela tem de renunciar à abstração, e chega assim junto a um ser que é precisamente o seu contrário, junto à natureza. Toda a lógica é, portanto, a prova de que o pensar abstrato por si nada é, de que a ideia absoluta por si nada é, de que somente a natureza é algo. (MARX, 2010a, p. 134)

Ao retomar a crítica de Feuerbach iniciada em 1839 à dialética de Hegel, Marx reafirmava a revalorização e o reestabelecimento da tentativa de elaboração de uma visão orgânica e onde a esfera da natureza se fundamentava 
sobre si mesma - também típica de uma época em que a filosofia e as ciências da natureza eram impulsionadas pelas consequências das revoluções industriais. Agora, ao aproximar tal noção de inspiração feuerbachiana das questões da economia política, o autor pôde começar a assentar as bases de uma compreensão racional entre o "metabolismo" do trabalho humano e a natureza, onde o início do desenvolvimento de sua crítica do "duplo caráter do trabalho" na sociedade capitalista atingirá seu auge em $O$ capital, quando escreve que "todo trabalho é, por um lado, dispêndio de força de trabalho do homem no sentido fisiológico, e nessa qualidade de trabalho humano igual ou trabalho humano abstrato gera o valor da mercadoria”. Nesse sentido, acrescentará Marx, "todo trabalho é, por outro lado, dispêndio de força de trabalho do homem sob forma especificamente adequada a um fim, e nessa qualidade de trabalho concreto útil produz valores de uso" (MARX, 1983, p. 53).

\section{Considerações finais}

Como se nota, encontra-se nos Manuscritos econômico-filosóficos de Karl Marx - e nas posições de 1844 como um todo - um importante momento no desenvolvimento do pensamento filosófico e científico do autor, uma vez que, ainda que não apresente sua noção posterior acabada, já evidencia alguns elementos que fundamentarão sua nova concepção materialista junto a Friedrich Engels. Além disso, a importância desses manuscritos também se mostra em relação aos debates e ruptura com os jovens hegelianos, a posição a Feuerbach e Hegel, bem como ao papel e função do encontro com as questões da economia política nesse processo. No mais, também se destacam as noções e interpretações que serão abandonadas, bem como outras que serão aprimoradas, durante o início do caminho que será percorrido na elaboração da crítica da economia política que será consolidada mais de duas décadas depois em $O$ capital.

Vemos, então, o quão importante foi a concepção e crítica do trabalho pelo jovem Marx, apesar destas estarem baseadas na divisão social do trabalho de Adam Smith e na dialética da dominação e servidão de Hegel. A partir de $A$ ideologia alemã , em meados de 1845-6, no entanto, ele anuncia seu abandono dessa relação sujeito-objeto e reelaborará o conceito de alienação, aderindo a uma nova filosofia materialista junto a Engels e fundando a análise filosóficacientífica da sociedade a partir das relações entre as "forças produtivas" e as "relações de produção". Isso não significaria, porém, o abandono completo da crítica ao conceito de trabalho, pelo contrário, pois com o encontro das questões do valor, Marx poderá amadurecer e fundamentar sobre as mesmas o fenômeno do "fetichismo da mercadoria" - apresentando-o filosoficamente como característico das relações de produção capitalistas. 
O ano de 1844 marcará, por tudo isso, na trajetória filosófica, política e pessoal de Karl Marx, o começo de um ponto de virada essencial para a constituição, junto a Friedrich Engels, de sua filosofia materialista e revolucionária. Como também buscamos indicar, a ascensão de um pensamento próprio e sua importância pode ser demonstrada a partir da superação teórica e prática em relação aos jovens hegelianos - desde Bruno Bauer, Max Stirner, e com mais ênfase o próprio Ludwig Feuerbach e Moses Hess (que agora passariam a "seguir" Marx) -, bem como de seu contraste com a posterior dissolução histórica do pós-hegelianismo pela falta de compreensão do núcleo racional da sociedade capitalista por seus intelectuais, permitindo que se tenham também uma melhor compreensão da importância e posição ocupadas na produção dos manuscritos de 1844 para o pensamento de Marx e no desenvolvimento da tradição pós-hegeliana.

\section{Referências bibliográficas}

BENSAÏD, Daniel. Espetáculo, fetichismo, ideologia. (Um livro inacabado.) Trad. e notas Samuel Weimar Cavalcante e Silva. Fortaleza: Plebeu Gabinete de Leitura/Expressão Gráfica e Editora, 2013. 132p.

HEGEL, G. W. F. Enciclopédia das ciências filosóficas: em compêndio (1830) v. I: a ciência da lógica. Trad. Paulo Meneses colab. Pe. José Machado. 3. ed. São Paulo: Edições Loyola, 2012. 448p.

JONES, Gareth Stedman. Karl Marx: grandeza e ilusão. Trad. Berilo Vargas. São Paulo: Companhia das Letras, 2017. 784p.

LOCKE, John. Segundo tratado sobre o governo. In: Carta acerca da tolerância; Segundo tratado sobre o governo; Ensaio acerca do entendimento humano. Trad. Anoar Aiex e E. Jacy Monteiro. 2. ed. São Paulo: Abril Cultural, 1978, pp. 31-131.

LÖWY, Michael. A teoria da revolução no jovem Marx. Trad. Anderson Gonçalves. Petrópolis: Vozes, 2002. 248p.

MANDEL, Ernest. A formação do pensamento econômico de Karl Marx: de 1843 até a redação de $O$ capital. Trad. Carlos Henrique de Escobar. Rio de Janeiro: Zahar Editores, 1968. 212p.

MARX, Karl. O capital: crítica da economia política v. 1. Trad. Regis Barbosa e Flávio R. Kothe. São Paulo: Abril Cultural, 1983 304p.

- Manuscritos econômico-filosóficos. Trad., apres. e notas Jesus

Ranieri. São Paulo: Boitempo, 2010a. 192p.

Sobre A questão judaica. Trad. Nélio Schneider. São Paulo: Boitempo, 2010b. 144p.

. Cadernos de Paris; Manuscritos econômico-filosóficos. Trad. José Paulo Netto e Maria Antónia Pacheco. São Paulo: Expressão Popular, 2015. 496p. 
. Manuscritos económico-filosóficos. Trad. Artur Morão. Lisboa: Edições 70, 2017. 248p.

. Ökonomisch-philosophische Manuskripte aus dem Jahre 1844. In: Karl Marx und Friedrich Engels Werke, Engänzungsband, 1. Dietz Verlag: Berlim (DDR), 1968, pp. 465-588. Disponível em: <http://www. mlwerke.de/me/me40/me40_465.htm>, acessado em: 3 mai. 2019.

NOVELLI, Pedro G. A. O idealismo de Hegel e o materialismo de Marx: demarcações questionadas. Tese (Doutorado) defendida na Universidade Estadual de Campinas (Unicamp), Campinas, 1998. Disponível em: <http://repositorio.unicamp.br/jspui/bitstream/REPOSIP/251086/1/Novell i_PedroGeraldoAparecido_D.pdf>, acessado em: 22 nov. 2019.

ROUSSEAU, Jean-Jacques. Discurso sobre a origem e os fundamentos da desigualdade entre os homens. Trad. Lourdes Santos Machado. 3. ed. São Paulo: Abril Cultural, 1983, pp. 201-320.

RUBIN, Isaac. História do pensamento econômico. Trad. Rubens Enderle. Rio de Janeiro: Editora UFRJ, 2014. 524p.

SAMPAIO, Benedicto Arthur; FREDERICO, Celso. Dialética e materialismo: Marx entre Hegel e Feuerbach. 2. ed. Rio de Janeiro: Editora UFRJ, 2009. $128 \mathrm{p}$.

VAZ, Henrique C. Lima. Senhor e escravo. Síntese - Revista de Filosofia, v. 8, n. 21, pp. 7-29, 1981. Disponível em: https://faje. edu.br/periódicos /index.php/Sintese/article/view/2175/2468, acessado em: 1 dez. 2019. WASZEK, Norbert. O estatuto da economia política na filosofia prática de Hegel. Trad. Danilo Vaz-Curado R. M. Costa. Revista Opinião Filosófica, n. 1, v. 2, jan./jun. 2011, pp. 56-72. Disponível em: <http://periodico. abavaresco.com.br/index.php/opiniaofilosofica/article/view/124/68>, acessado em: 7 abr. 2019.

Como citar:

MARTINS, Douglas Rafael Dias. Os Manuscritos de 1844 de Karl Marx e a retomada da economia política no pensamento pós-hegeliano. Verinotio Revista on-line de Filosofia e Ciências Humanas, Rio das Ostras, v. 26, n. 1, pp. 301-29, jan./jun. 2020.

Data do envio: 15 maio 2020

Data do aceite: 8 jun. 2020 